DOI https://doi.org/10.36059/978-966-397-240-4-14

Крамаренко О. С.

кандидат сільськогосподарських наук, доцент кафедри технології переробки, стандартизації

і сертифікації продукції тваринництва

Миколаївський національний аграрний університет

м. Миколаїв

Крамаренко С. C.

доктор біологічних наук, професор,

професор кафедри генетики, годівлі тварин та біотехнології

Миколаївський національний аграрний університет

м. Миколаїв

\title{
АСОЦІАЦІЯ МІЖ ГЕТЕРОЗИГОТНІСТЮ ЗА МІКРОСАТЕЛІТАМИ ДНК ТА ПРОДУКТИВНІСТЮ СІЛЬСЬКОГОСПОДАРСЬКИХ ТВАРИН
}

Анотація. Основною метою нашої роботи було визначення зв'язку між гетерозиготністю (як на рівні окремих локусів, так й індивідуальною оцінкою мультилокусної гетерозиготності) за локусами мікросателітів ДНК (МС-ДНК) та продуктивністю сільськогосподарських тварин, а саме ознаками відтворення свиноматок великої білої породи та живою масою телиць південної м'ясної породи.

Для свиноматок великої білої породи відмічено переважання особин із гомозиготним генотипом над гетерозиготами у відношенні показників багатоплідності та, відповідно, протилежна картина у відношенні кількості та частки мертвонароджених поросят у гнізді. Кореляція між гетерозиготністю та ознаками відтворення мала негативний знак для більшості використаних в аналізі локусів МС-ДНК, що пов'язано із схрещуванням племінних тварин різного походження (англійської та угорської селекції) та, відповідно, проявом аутбредної депресії.

Для телиць південної м'ясної породи встановлено вірогідний вплив локусу ВМ2113 на живу масу у віці 15 міс. та локусу ВМ1818 на живу масу у віці 8 міс. та наявність асоціації між живою масою та оцінками міри d² для чотирьох локусів МС-ДНК (ВM2113, SPS115, ЕТН3 та ВМ1824). Виявлені зв'язки у більшості випадків мали 
позитивний знак, тобто, чим більше різниця між довжиною алелів МС-ДНК в межах індивідуального генотипу, тим вище жива маса телиць.

Таким чином, характер зв'язку між гетерозиготністю та продуктивністю серед досліджених груп свиней та худоби в значній мірі залежав як від походження тварин, так і напряму селекційноплемінної роботи в господарствах.

\section{Вступ}

При організації селекційної роботи серед сільськогосподарських тварин значною проблемою $\epsilon$ схрещування між близькими родичами, тобто, організмами, які мають спільного предка i отримали від обох батьків однакові алельні копії ідентичні за походженням (identical by descent). В геномі нащадків від таких схрещувань збільшується кількість локусів, що мають два функціонально подібних алеля і, таким чином, знижується рівень гетерозиготності. Наслідками цих процесів $\epsilon$ інбредна депресія (inbreeding depression), що негативно впливає на компоненти загальної пристосованості організму (виживаність, репродуктивний успіх, ріст та розвиток, тощо), а для сільськогосподарських тварин - ще й рівень продуктивності $[8 ; 14 ; 32]$.

Але 3 іншого боку не менша увага повинна приділятися аутбридингу, тобто, схрещуванню між віддалено спорідненими особинами, наприклад, тварин із різних популяцій або підвидів. В цьому випадку можна очікувати як підвищення загальної пристосованості внаслідок зростання рівня гетерозиготності (прояв «гібридної сили» - hybrid vigor), так й, навпаки, її зниження, що може бути спричинено аутбредною депресією (outbreeding depression). Описано три основні механізми, що можуть бути відповідальними за прояв аутбредної депресії: 1) хромосомні порушення, що призводять до часткової або повної стерильності гібридів $\mathrm{F}_{1}$; 2) адаптивна диференціація між популяціями; 3) ефект «Пляшкового горлечка» (bottleneck effect) та генетичний дрейф [13].

Не зважаючи на те, що a priori мікросателіти ДНК (МС-ДНК) $\epsilon$ нейтральними молекулярно-генетичними маркерами, починаючи 3 середини 1990-х років почали з'являтися докази наявності вірогідних асоціацій між присутністю певних алелів локусів MC-ДНК в генотипі із ознаками продуктивності сільськогосподарських тварин [3]. Паралельно з цим було встановлено, що рівень гетерозиготності в популяціях диких тварин як за окремими 
структурними генами і локусами МС-ДНК, так й індивідуальні оцінки мультилокусної гетерозиготності, мали позитивний вплив на розвиток ознак, пов'язаних із загальною пристосованістю особин. Прояв такого зв'язку набув визначення «кореляції між гетерозиготністю та пристосованістю» (heterozygosity-fitness correlations, HFCs) і першою роботою, де було продемонстровано цей феномен $\epsilon$ піонерське дослідження [33] на устриці. Дві основні гіпотези було висунуто для пояснення цього феномену й обидві вони розглядають важливість таких типів міжалельної взаємодії, як домінування та наддомінування (гетерозис), а також нерівноважне зчеплення між алелями різних генів [40]. При цьому, оскільки було доведено, що кореляція має місце не лише із гетерозиготністю структурних генів, але й нейтральних МС-ДНК, більш обгрунтованою вважається гіпотеза «асоціативного наддомінування» (associative overdominance) [15; 17].

Хоча негативні наслідки інбридингу та зниження гетерозиготності на відтворювальні якості та виживаність в популяціях диких тварин вже добре вивчено, відомо небагато досліджень щодо ïx впливу на ознаки продуктивності у свійських та сільськогосподарських тварин. Протягом останніх 20 років з'явилася низка публікацій, що розглядають вплив різних оцінок гетерозиготності (коефіцієнт інбридингу, гетерозиготність та міра $d^{2}$ як для окремих структурних генів та локусів МС-ДНК, так й їх мультилокусна оцінка) на ознаки тварин, які розводяться в штучних умовах риб [7], хутрових звірів [19], курей [21] та качок [6], свиней [16; 17; $22 ; 38 ; 39]$, кіз [15], коней [11; 25], овець [34; 36], яків [18] та худоби [12].

Таким чином, основною метою нашої роботи було визначення зв'язку між гетерозиготністю (як на рівні окремих локусів, так й індивідуальною оцінкою мультилокусної гетерозиготності) за локусами МС-ДНК та продуктивністю сільськогосподарських тварин, а саме ознаками відтворення свиноматок великої білої породи та живою масою телиць південної м'ясної породи.

\section{1. Асоціація між гетерозиготністю та ознаками відтворення свиноматок великої білої породи}

Дослідження було проведено на поголів'ї свиноматок великої білої породи (ВБП), які утримувалися в умовах двох господарств: ТОВ «Таврійські свині» Херсонської області $(n=51)$ та СГПП «Техмет-Юг» Миколаївської області $(n=72)$. 
У дослідженні було використано 11 локусів мікросателітів ДНК, що рекомендовані Міжнародною спілкою генетики тварин (ISAG) S0101, S0155, S0228, S0355, S0386, Sw24, Sw72, Sw240, Sw857, Sw936 та $S w 951$. Усі лабораторні дослідження було проведено в умовах Лабораторії молекулярних основ селекції тварин Центру біотехнології та молекулярної діагностики Федерального наукового центру тваринництва ім. академіка Л. К. Ернста. Методи лабораторного аналізу детально описано в [23].

Для кожного локусу МС-ДНК була визначена кількість гомозиготних та гетерозиготних особин і розрахована оцінка фактичної гетерозиготності на локус $(S L H)$. Для кожної особини було визначено оцінку мультилокусної гетерозиготності $(M L H)$, як частка локусів МС-ДНК, що знаходилися у гетерозиготному стані від загальної кількості локусів, за якими дану особину було генотиповано.

Крім того, для кожної свиноматки за кожним локусом МС-ДНК було розраховано оцінки міри $d^{2}$, як квадрат різниці між довжиною обох алелів (в кількості тандемних повторів) в індивідуальному генотипі. Середню мультилокусну оцінку $d^{2}$ (mean $d^{2}$ ) було розраховано для всіх локусів, за якими дану особину було генотиповано, згідно [10].

Для кожної свиноматки також було оцінено наступні ознаки відтворення: загальна кількість поросят при народженні (TNB total no. piglets born), багатоплідність (NBA - no. piglets born alive), кількість мертвонароджених поросят (NSB - no. of stillborn piglets), частка мертвонароджених поросят (FSB - freq. of stillborn piglets) та кількість поросят при відлученні (NW - no. weaned piglets) протягом перших п'яти опоросів.

Для перевірки гіпотези щодо відсутності впливу генотипу (гомо- чи гетерозиготний) за локусом МС-ДНК на ознаки відтворення свиноматок ВБП було використано критерій Стьюдента. Для перевірки гіпотези щодо відсутності зв'язку між залежною ознакою (ознаки відтворення) та мірою $d^{2}$ було використано коефіцієнт рангової кореляції Спірмена $(R s)$. Аналізи було проведено окремо для кожного господарства, кожного локусу MC-ДНК та для кожної залежної ознаки.

Для перевірки гіпотези щодо відсутності зв'язку між залежною ознакою (ознаки відтворення) та індивідуальними оцінками як мультилокусної гетерозиготності $(M L H)$, так і міри mean $d^{2}$, було використано алгоритм дисперсійного аналізу Р.Фішера, де у якості факторної змінної було використано градації ознак. Оцінки $M L H$ було згруповано у сім класів: менше $0,400,0,401-0,500,0,501-0,600$, $0,601-0,700,0,701-0,800,0,801-0,900$ та більше 0,901. Оцінки 
середньої мультилокусної оцінки міри mean $d^{2}$ також було згруповано у сім класів: менше 5,0, 5,1-10,0, 10,1-15,0, 15,1-20,0, 20,1-25,0, 25,1-30,0 та більше 30,1 тандемних повторів ${ }^{2}$.

Порівняння частки гомо- та гетерозиготних особин за кожним локусом МС-ДНК в двох господарствах було проведено за допомогою точного критерію Фішера $\left(P_{F}\right)$, а порівняння оцінок міри $d^{2}$ - за допомогою непараметричного тесту Манна-Уітні. Всю статистичну обробку було проведено на підставі посібника [4] за допомогою програмного забезпечення STATISTICA v.7 (Stat Soft Inc.)

Оцінки фактичної гетерозиготності (тобто, частка особин, які мали гетерозиготний генотип) для досліджених свиноматок ВБП варіювали в значних межах - від 0,386 (локус $S w 240$; СГПП «ТехметЮг») до 0,812 (локус Sw857; СГПП «Техмет-Юг»), при цьому, вірогідні відмінності між тваринами з різних господарств було встановлено лише для локусів $S 0155$ та $S w 240$. При цьому, особини СГПП «Техмет-Юг» в обох випадках поступалися свиноматкам з ТОВ «Таврійські свині» (табл. 1).

Таблиця 1

Показники мінливості $(M e a n \pm S E)$ гетерозиготності $(S L H)$ та оцінки міри $d^{2}$ за локусами МС-ДНК свиноматок ВБП різних господарств

\begin{tabular}{|c|c|c|c|c|c|c|}
\hline \multirow[b]{2}{*}{ Локус } & \multicolumn{3}{|c|}{$S L H$} & \multicolumn{3}{|c|}{ Mipa $d^{2}$} \\
\hline & \begin{tabular}{|c|} 
ТОВ \\
«Таврійські \\
свині» \\
$(n=51)$ \\
\end{tabular} & $\begin{array}{c}\text { СгПП } \\
\text { «Техмет- } \\
\text { Юг» }(n=72)\end{array}$ & $\boldsymbol{P}_{F}$ & $\begin{array}{c}\text { ТОВ } \\
\text { «Таврійські } \\
\text { свині» } \\
(n=51) \\
\end{array}$ & $\begin{array}{c}\text { СГПП } \\
\text { «Техмет- } \\
\text { Юг» } \\
(n=72) \\
\end{array}$ & $\begin{array}{l}\text { M-W } \\
\text { тест }\end{array}$ \\
\hline S0101 & $0,765 \pm 0,060$ & 0,6 & ns & $10,67 \pm 3,27$ & $16,15 \pm 3,30$ & 110 \\
\hline S0155 & $0,706 \pm 0$ & 0,4 & 0,005 & $13,43 \pm 2,46$ & $4,20 \pm 1,27$ & 3,19 \\
\hline S0228 & $0,686 \pm$ & 0,73 & ns & $11,27 \pm 3,54$ & $10,24 \pm 2,61$ & ns \\
\hline S0355 & $0,745=$ & 0,73 & ns & $75,18 \pm 10,62$ & $47,07 \pm 7,27$ & ns \\
\hline S0386 & $0,500 \pm$ & $0,529 \pm$ & ns & $9,34 \pm 1,87$ & $7,54 \pm 1,18$ & ns \\
\hline Sw24 & $0,633 \pm 0$ & $0,605 \pm$ & ns & $9,12 \pm 4,81$ & $6,98 \pm 1,71$ & ns \\
\hline Sw72 & $0,725 \pm 0,063$ & $0,706 \pm 0,056$ & ns & $6,29 \pm 1,23$ & $13,19 \pm 1,69$ & $2,22^{*}$ \\
\hline Sw240 & $0,725 \pm 0,063$ & $0,386 \pm 0,059$ & $<0,001$ & $29,00 \pm 5,20$ & $6,33 \pm 2,01$ & $4,52^{* *}$ \\
\hline Sw857 & $0,720 \pm 0,064$ & $0,812 \pm 0,047$ & ns & $6,66 \pm 1,60$ & $11,49 \pm 1,69$ & ns \\
\hline Sw936 & $0,667 \pm 0,067$ & $0,657 \pm 0,058$ & ns & $19,04 \pm 4,10$ & $19,90 \pm 3,00$ & ns \\
\hline Sw951 & $0,647 \pm 0,068$ & $0,696 \pm 0,056$ & ns & $3,75 \pm 0,85$ & $4,81 \pm 0,82$ & ns \\
\hline
\end{tabular}

Примітка: ${ }^{*}-P<0,05 ;{ }^{* *}-P<0,01 ;{ }^{* * *}-P<0,001 ;$ ns $-P>0,05$. $P_{F}$ - результати точного критерію Фішера. M-W тест - результати непараметричного тесту Манна-Уітні. 
Оцінки міри $d^{2}$ також коливалися в досить значних межах - від 3,75 (локус $S w 951$; ТОВ «Таврійські свині») до 75,18 (локус S0355; ТОВ «Таврійські свині») тандемних повторів ${ }^{2}$. Результати непараметричного тесту Манна-Уітні свідчать, що вірогідні відмінності між тваринами різних господарств у відношенні оцінок цього показника було відмічено для трьох локусів - S0155, Sw72 та $S w 240$. При цьому, в першому та третьому випадках знову ж таки переважали особини з ТОВ «Таврійські свині», а для локусу $S w 72$ вони, навпаки, поступалися свиноматкам СГПП «Техмет-Юг» (див. табл. 1).

311 використаних в аналізі локусів МС-ДНК, лише для двох не було встановлено вірогідних відмінностей між особинами із гомота гетерозиготним генотипом серед особин обох господарств - для $S 0155$ та $S w 857$. Для решти локусів вплив генотипу мав місце серед особин ТОВ «Таврійські свині» для трьох, а серед особин СГПП «Техмет-Юг» - для восьми локусів (табл. 2).

Таблиця 2

Вплив генотипу (гомо- чи гетерозиготний) за локусами МС-ДНК на ознаки відтворення свиноматок ВБП різних господарств

\begin{tabular}{|c|c|c|c|c|}
\hline \multirow[t]{2}{*}{ Локус } & \multicolumn{2}{|c|}{$\begin{array}{c}\text { ТОВ «Таврійські свині» } \\
(n=51)\end{array}$} & \multicolumn{2}{|c|}{$\begin{array}{c}\text { СГПП «Техмет-Юг» } \\
(n=72)\end{array}$} \\
\hline & Ознака & Різниця & Ознака & Різниця \\
\hline$S 0101$ & ns & - & $\begin{array}{c}\text { TNB2 }\left(^{*}\right) ; \underset{(* *)}{\text { NBA2 }}\left({ }^{* *}\right) ; \text { NW2 } \\
\end{array}$ & $\mathrm{Hm}>\mathrm{Ht}$ \\
\hline & & & $\begin{array}{c}\text { TNB3 }\left(^{*}\right) ; \mathrm{NBA3}\left({ }^{*}\right) ; \mathrm{NW} 3 \\
(*)\end{array}$ & $\mathrm{Hm}>\mathrm{Ht}$ \\
\hline S0155 & ns & - & ns & - \\
\hline S0228 & $\begin{array}{c}\text { NSB1 }(* *) ; \text { FSB1 } \\
(*)\end{array}$ & $\mathrm{Hm}<\mathrm{Ht}$ & ns & - \\
\hline S0355 & ns & - & NW3 $\left(^{*}\right)$ & $\mathrm{Hm}>\mathrm{Ht}$ \\
\hline S0386 & ns & - & NSB3 $(*) ;$ FSB3 $(*)$ & $\mathrm{Hm}<\mathrm{Ht}$ \\
\hline Sw24 & ns & - & $\begin{array}{c}\text { TNB3 }\left(^{* *}\right) ; \text { NBA3 }\left({ }^{* * *}\right) ; \\
\text { NW3 }(*)\end{array}$ & $\mathrm{Hm}>\mathrm{Ht}$ \\
\hline Sw72 & ns & - & $\begin{array}{c}\text { TNB2 }(*) ; \underset{N B A 2}{ }(*) ; \mathrm{NW} 2 \\
(*)\end{array}$ & $\mathrm{Hm}>\mathrm{Ht}$ \\
\hline$S w 240$ & ns & - & NW1 $\left({ }^{* *}\right) ; \operatorname{NBA} 3\left(^{*}\right)$ & $\mathrm{Hm}>\mathrm{Ht}$ \\
\hline Sw857 & ns & - & ns & - \\
\hline Sw936 & NSB5 $\left(^{*}\right)$ & $\mathrm{Hm}>\mathrm{Ht}$ & NW1 (*) & $\mathrm{Hm}>\mathrm{Ht}$ \\
\hline Sw951 & $\begin{array}{c}\text { NBA4 }(*) ; \text { NBA5 } \\
\left({ }^{*}\right)\end{array}$ & $\mathrm{Hm}>\mathrm{Ht}$ & NW4 (*); NW5 (*) & $\mathrm{Hm}>\mathrm{Ht}$ \\
\hline
\end{tabular}

Примітка: $\mathrm{Hm}$ - гомозиготний генотип; $\mathrm{Ht}$ - гетерозиготний генотип. 
Найчастіше вірогідні відмінності було відмічено для ознак відтворення свиноматок протягом II-го та III-го опоросів. Лише для локусу $S w 951$ такі відмінності стосувалися рівня відтворювальних якостей серед самих дорослих тварин, що використано в аналізі (IV-го та V-го опоросів).

Характерною особливості отриманих результатів $€$ переважання особин із гомозиготним генотипом над гетерозиготами у відношенні показників багатоплідності (TNB, NBA та NW) та, відповідно, протилежна картина у відношенні кількості та частки мертвонароджених поросят у гнізді (NSB та FSB). Лише в одному випадку (локус $S w 936$; ТОВ «Таврійські свині») свиноматки із гетерозиготним генотипом мали вірогідно меншу кількість мертвонароджених поросят протягом V-го опоросу.

Для всіх досліджених локусів МС-ДНК було встановлено наявність вірогідного зв'язку між оцінками міри $d^{2}$ за локусами MCДНК та ознаками відтворення свиноматок ВБП, хоча, знову ж таки, серед особин ТОВ «Таврійські свині» така асоціація зустрічалася значно рідше, ніж серед особин СГПП «Техмет-Юг» (табл. 3).

Отримані результати у більшості випадків свідчать про зниження показників багатоплідності та, відповідно, збільшення кількості/частки мертвонароджених поросят у гнізді із зростанням оцінок міри $d^{2}$, тобто, із зростанням ступеню відмінності між довжиною обох алелів в індивідуальному генотипі.

Протилежну картину було відмічено лише при дослідженні локусів $S w 857$ (для обох господарств) та $S w 951$ (для ТОВ «Таврійські свині»). В цих випадках зростання оцінок міри $d^{2}$ призводило до збільшення загальної кількості поросят при народженні протягом I-II-го та IV-го опоросів, відповідно. Аналогічні (за сенсом) результати було відмічено для кількості/частки мертвонароджених поросят у гнізді свиноматок ТОВ «Таврійські свині» протягом IV-го (локус $S w 240$ ) та V-го (локус $S w 936)$ опоросів (див. табл. 3). Таким чином, в більшості випадків було зафіксовано прояв негативних HFCs.

Що стосується індивідуальних оцінок мультилокусної гетерозиготності (MLH) та оцінок міри mean $d^{2}$ за локусами MC-ДНК серед свиноматок ВБП з обох господарств, то, в цілому, особини СГПП «Техмет-Юг» характеризувалися більш низьким рівнем генетичної мінливості, але вірогідні відмінності було встановлено лише у відношенні міри теаn $d^{2}$ (непараметричний тест МаннаУітні: $P<0,05$ ) (табл. 4). 
Таблиця 3

Коефіцієнти рангової кореляції Спірмена (Rs) між оцінками міри $d^{2}$ за локусами МС-ДНК та ознаками відтворення свиноматок ВБП різних господарств

\begin{tabular}{|c|c|c|}
\hline Локус & $\begin{array}{c}\text { ТОВ «Таврійські свині» } \\
(n=51)\end{array}$ & $\begin{array}{c}\text { СГПП «Техмет-Юг» } \\
(n=72)\end{array}$ \\
\hline S0101 & ns & $\begin{array}{l}\text { TNB3 }\left(-0,303^{*}\right) \\
\text { NBA3 }\left(-0,311^{*}\right)\end{array}$ \\
\hline S0155 & ns & TNB1 $\left(-0,247^{*}\right)$ \\
\hline S0228 & NSB1 (0,387*), FSB1 $\left(0,377^{*}\right)$ & ns \\
\hline$S 0355$ & ns & $\begin{array}{l}\text { NSB2 }\left(0,403^{* *}\right) ; \\
\text { FSB2 }\left(0,404^{* *}\right) ; \\
\text { NW2 }\left(-0,371^{* *}\right) ; \\
\text { NBA3 }\left(-0,359^{*}\right) ; \\
\text { NW3 }\left(-0,378^{*}\right)\end{array}$ \\
\hline S0386 & ns & NSB5 $\left(0,639^{*}\right) ;$ FSB5 $\left(0,635^{*}\right)$ \\
\hline Sw24 & ns & $\begin{array}{l}\text { TNB3 }\left(-0,543^{* *}\right) ; \\
\text { NBA3 }\left(-0,593^{* * *}\right) ; \\
\text { NW3 }\left(-0,405^{*}\right)\end{array}$ \\
\hline Sw72 & ns & $\begin{array}{l}\text { TNB2 }\left(-0,298^{*}\right) ; \\
\text { NBA2 }\left(-0,309^{*}\right) ; \\
\text { NW2 }\left(-0,277^{*}\right)\end{array}$ \\
\hline Sw240 & NSB4 $(-0,402 *) ;$ FSB4 $(-0,407 *)$ & NW1 $\left(-0,375^{* *}\right)$ \\
\hline Sw857 & TNB1 $\left(0,344^{*}\right)$ & TNB2 $\left(0,283^{*}\right)$ \\
\hline Sw936 & $\begin{array}{c}\text { NBA2 }(-0,331) ; \text { TNB5 }(- \\
\left.0,445^{* *}\right) ; \\
\text { NSB5 }\left(-0,333^{*}\right)\end{array}$ & NW1 $\left(-0,260^{*}\right)$ \\
\hline Sw951 & TNB4 $\left(0,338^{*}\right)$ & $\begin{array}{l}\text { NW1 }\left(-0,323^{*}\right) ; \text { NW4 }\left(-0,559^{*}\right) \\
\text { NSB1 }\left(0,292^{*}\right) ; \text { FSB1 }\left(0,289^{*}\right)\end{array}$ \\
\hline
\end{tabular}

Примітка: Наведено лише вірогідні оцінки коефіцієнту рангової кореляції Спірмена.

Таблиця 4

Показники мінливості (Mean $\pm S E)$ індивідуальних оцінок мультилокусної гетерозиготності (MLH) та оцінок міри теan $d^{2}$ за локусами МС-ДНК свиноматок ВБП різних господарств

\begin{tabular}{|c|c|c|c|c|c|}
\hline \multirow{2}{*}{$\begin{array}{c}\text { Показ- } \\
\text { ник }\end{array}$} & $\begin{array}{c}\text { T0В «Таврійські свині» } \\
(\boldsymbol{n}=\mathbf{5 1})\end{array}$ & \multicolumn{2}{c|}{$\begin{array}{c}\text { СГПП «Техмет-Юг» } \\
(\boldsymbol{n}=\mathbf{7 2})\end{array}$} & $\begin{array}{c}\text { М-W } \\
\text { тест }\end{array}$ \\
\cline { 2 - 6 } & $\mathbf{m i n}-\mathbf{m a x}$ & Mean $\pm \boldsymbol{S E}$ & $\mathbf{m i n}-\mathbf{m a x}$ & Mean $\pm \boldsymbol{S E}$ & \\
\hline$M L H$ & $0,200-1,000$ & $0,683 \pm 0,022$ & $0,200-1,000$ & $0,625 \pm 0,020$ & ns \\
\hline mean $d^{2}$ & $1,82-39,45$ & $17,64 \pm 1,45$ & $0,56-32,20$ & $13,26 \pm 0,92$ & $2,22^{*}$ \\
\hline
\end{tabular}


Розподіл за індивідуальними оцінками мультилокусної гетерозиготності за локусами МС-ДНК свиноматок ВБП різних господарств мав асиметричну форму із довгим «хвостом» у бік низьких значень (рис. 1А).

Очікувано, частка особин у СГПП «Техмет-Юг» із дуже високими оцінками $M L H$ (вище 0,800) була майже вдвічі нижче, ніж серед свиноматок ТОВ «Таврійські свині». Що стосується особливостей розподілу за індивідуальними оцінками міри mean $d^{2}$ за локусами MCДНК, то для свиноматок СГПП «Техмет-Юг» він має унімодальну асимет-ричну форму з довгим «хвостом» у бік високих значень. Для особин ТОВ «Таврійські свині» цей розподіл має бімодальну форму (рис. 1B).

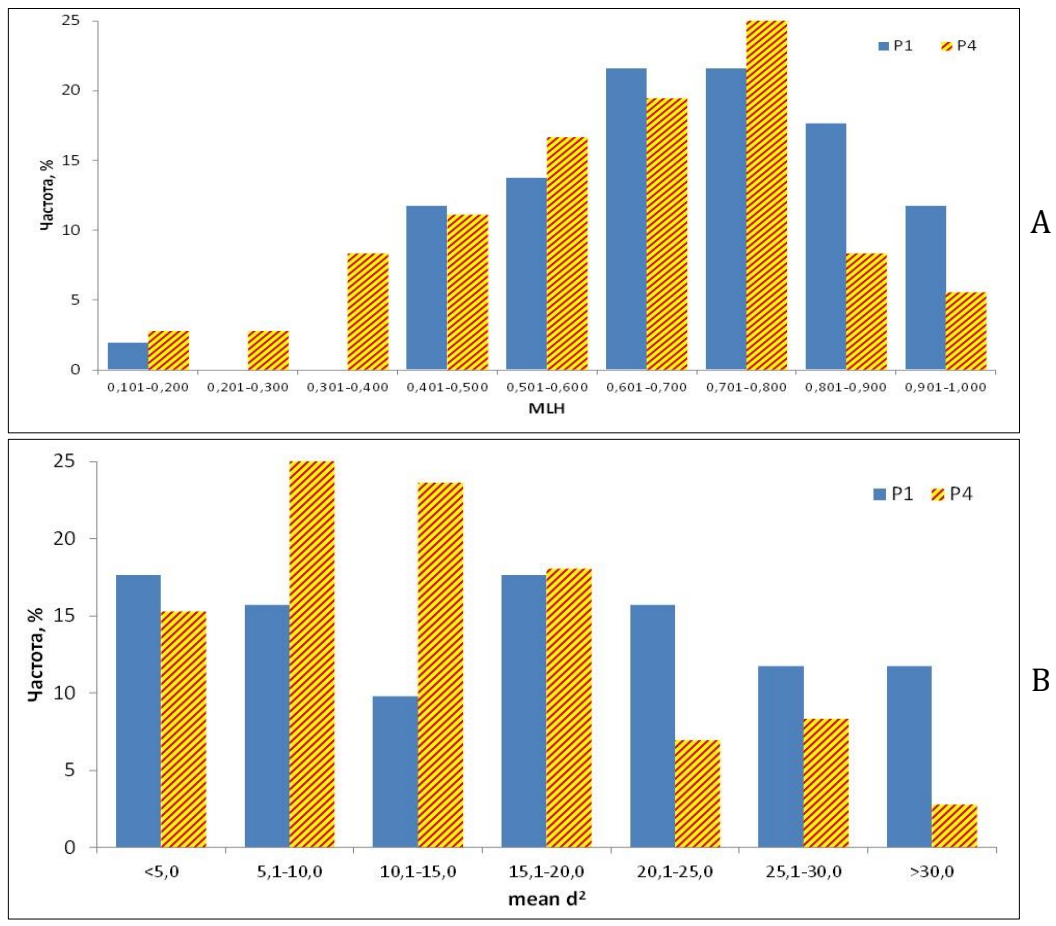

Рис. 1. Розподіл індивідуальних оцінок мультилокусної гетерозиготності (A) та міри mean $d^{2}$ (B) за локусами МС-ДНК свиноматок ВБП різних господарств: Р1 - ТОВ «Таврійські свині»; Р4 - СГПП «Техмет-Юг» 
Вірогідний вплив індивідуальних оцінок мультилокусної гетерозиготності було встановлено лише на багатоплідність та кількість поросят при відлучення протягом III-го опоросу і лише в одному господарстві - СГПП «Техмет-Юг» (для NBA3: $F_{6 ;} 39=2,34$; $P=0,050$; для NW3: $\left.F_{6 ;} 38=2,80 ; P=0,024\right)$. При цьому, середні оцінки ознак відтворення були найбільшими для тварин із індивідуальними оцінками мультилокусної гетерозиготності в межах 0,401-0,500 та знижувалися із зростанням рівня їх гетерозиготності. 3 іншого боку, багатоплідність свиноматок також мала тенденцію до зниження серед тварин із дуже низькими оцінками мультилокусної гетерозиготності (рис. 2А).

Характерно, що вплив індивідуальних оцінок міри теаn $d^{2}$ за локусами МС-ДНК на багатоплідність як при народженні, так й при відлученні, що також було встановлено для свиноматок під час III-го опоросу, був значно сильніший (у всіх випадках: $P=0,001-0,014)$. Таким чином, не стільки факт гетерозиготності впливав на ознаки відтворення свиноматок, скільки ступінь відмінностей в довжині алелів в індивідуальному генотипі.

В цілому, спостерігалася вірогідна тенденція до зниження рівня багатоплідності свиноматок ВБП із зростанням індивідуальних оцінок міри mean $d^{2}$ за дослідженими локусами МС-ДНК, що може слугувати проявом аутбредної депресії (рис. 2В).

Дослідження було проведено на поголів'ї телиць таврійського внутрішньопородного типу південної м'ясної породи (ПМП) (загалом - 192 голови) ДП «ДГ Асканійське» Асканійської державної сільськогосподарської дослідної станції Інституту зрошуваного землеробства НААН Каховського району Херсонської області. Частина з них представляла низькокровний за зебу підтип (НК), а інша частина - висококровний за зебу підтип (ВК) [2].

У дослідженні було використано 10 мікросателітних локусів, що рекомендовані Міжнародною спілкою генетики тварин (ISAG) TGLA227, BM2113, TGLA53, ETH10, SPS115, TGLA122, INRA023, BM1818, ETH3 та BM1824. Усі лабораторні дослідження було проведено в умовах Лабораторії молекулярних основ селекції тварин Центру біотехнології та молекулярної діагностики Федерального наукового центру тваринництва ім. академіка Л. К. Ернста. Методи лабораторного аналізу детально наведено в [2].

Для кожного локусу МС-ДНК була визначена кількість гомозиготних (Nhom) та гетерозиготних (Nhet) особин і розраховані оцінки фактичної гетерозиготності на локус $(S L H)$. 


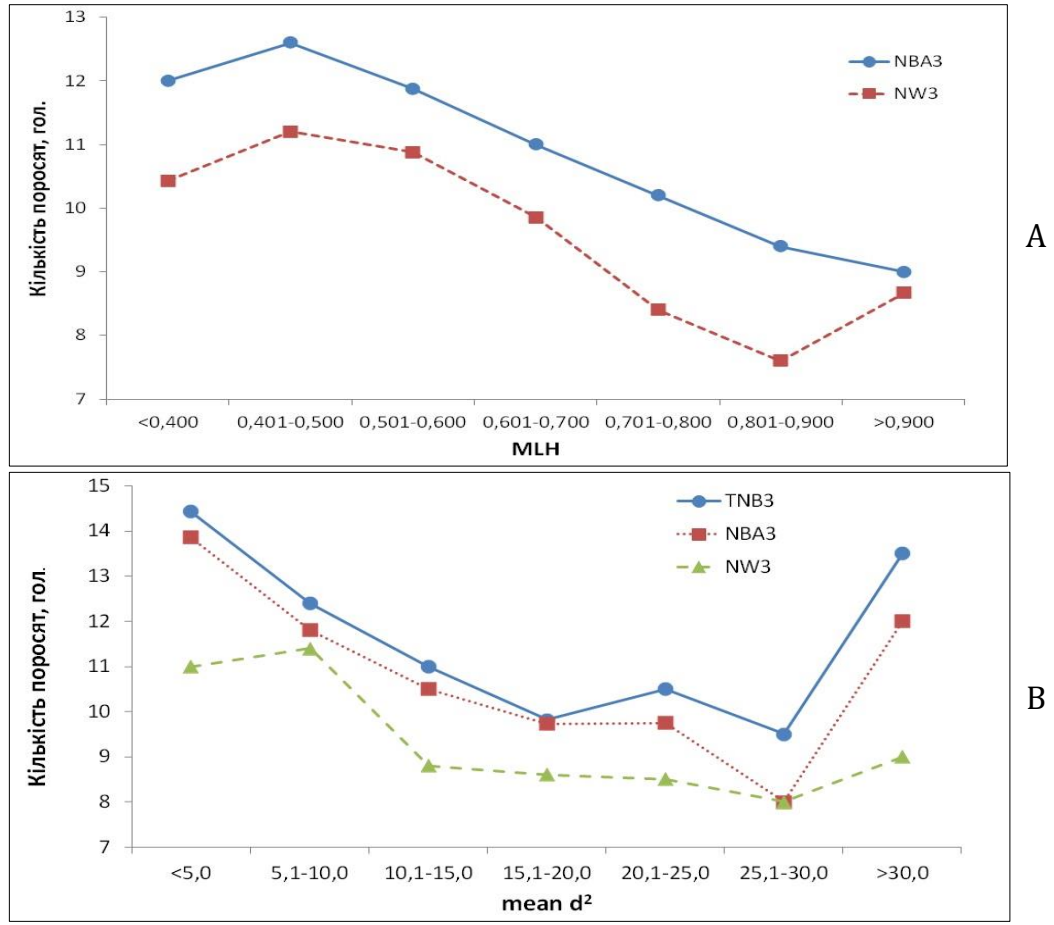

Рис. 2. Вплив індивідуальних оцінок мультилокусної

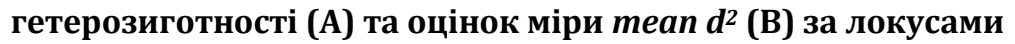
МС-ДНК на ознаки відтворення свиноматок ВБП III-го опоросу в умовах СГПП «Техмет-Юг»

\section{2. Асоціація між гетерозиготністю та живою масою телиць південної м'ясної породи}

Для кожної особини було визначено значення мультилокусної гетерозиготності $(M L H)$, як частка локусів МС-ДНК, що знаходилися у гетерозиготному стані від загальної кількості локусів, за якими дану особину було генотиповано.

Крім того, для кожної телиці за кожним локусом МС-ДНК були розраховані абсолютна різниця між довжиною обох алелів (в кількості тандемних повторів) в індивідуальному генотипі (IDA) та міра $d^{2}$, як квадрат різниці між довжиною обох алелів (в кількості тандемних повторів) в індивідуальному генотипі. Середню 
мультилокусну оцінку міри $d^{2}$ (mean $d^{2}$ ) було розраховано для всіх локусів, за якими дану особину було генотиповано, згідно [10].

Із фенотипових ознак для кожної телиці були використані наступні (в кг): жива маса при народженні (WB), при відлученні (WW), у віці 8 міс. (W8), 12 міс. (W12), 15 міс. (W15) та 18 міс. (W18).

Оскільки жива маса телиць вірогідно відрізнялась серед особин різних підтипів (табл. 5), було використано алгоритм двофакторного дисперсійного аналізу, де у якості фіксованих факторів мінливості залежної ознаки (жива маса у різному віці) було розглянуто вплив належності телиці до певного підтипу (НК або ВК), вплив генотипу за певним локусом МС-ДНК (гомо- чи гетерозиготний), а також їх сумісний вплив. Аналіз було проведено окремо для кожного локусу МС-ДНК для кожної залежної ознаки.

Для перевірки гіпотези щодо відсутності зв'язку між залежною ознакою (жива маса у різному віці) та мірою $d^{2}$ було використано коефіцієнт рангової кореляції Спірмена $(R s)$. Аналіз було проведено окремо для кожного підтипу, кожного локусу МС-ДНК та для кожної залежної ознаки.

Таблиця 5

Показники мінливості $(M e a n \pm S E)$ живої маси телиць ПМП різних підтипів в різному віці, кг

\begin{tabular}{|c|c|c|}
\hline \multirow{2}{*}{ Ознака } & \multicolumn{2}{|c|}{ Підтип } \\
\cline { 2 - 3 } & $\begin{array}{c}\text { низькокровний (НК) } \\
(\boldsymbol{n}=\mathbf{3 6})\end{array}$ & $\begin{array}{c}\text { висококровний (ВК) } \\
(\boldsymbol{n}=\mathbf{3 8})\end{array}$ \\
\hline WB & $23,8 \pm 0,5$ & $21,8 \pm 0,5^{* *}$ \\
\hline WW & $193,4 \pm 5,3$ & $168,6 \pm 5,0^{* *}$ \\
\hline W8 & $205,1 \pm 5,6$ & $187,4 \pm 5,7^{*}$ \\
\hline W12 & $247,7 \pm 6,9$ & $216,6 \pm 6,5^{* *}$ \\
\hline W15 & $295,9 \pm 9,8$ & $263,8 \pm 6,9^{* *}$ \\
\hline W18 & $351,5 \pm 12,3$ & $315,7 \pm 7,6^{*}$ \\
\hline
\end{tabular}

Для перевірки гіпотези щодо відсутності зв'язку між залежною ознакою (жива маса у різному віці) та індивідуальними оцінками мультилокусної гетерозиготності $(M L H)$ і міри mean $d^{2}$ було використано алгоритм дисперсійного аналізу, де у якості факторної змінної було використано градації ознак. Оцінки $M L H$ було згруповано у шість класів: менше 0,50, 0,51-0,60, 0,61-0,70, 0,71-0,80, 0,81-0,90 та більше 0,91. Оцінки середньої мультилокусної міри теan $d^{2}$ також було згруповано у шість класів: менше 5,0, 5,1-10,0, 10,1-15,0, 15,1-20,0, 20,1-25,0 та більше 25,1. 
Всю статистичну обробку було проведено на підставі посібника [4] за допомогою програмного забезпечення STATISTICA v.7 (Stat Soft Inc.).

В цілому для всіх проаналізованих локусів МС-ДНК відмічалися суттєві відмінності у кількості особин, які мають гомо- та гетерозиготний генотип (критерій хі-квадрат: $\chi^{2}=139,54 ; d f=9$; $P<0,001)$ та, відповідно, у відношенні оцінки фактичної гетерозиготності (табл. 6). Найнижчу оцінку гетерозиготності було відмічено для локусу TGLA53 $(0,421)$, а найвищу - для локусу BM1818 (0,820).

Ступінь прояву гетерозиготності (тобто, квадрат різниці між довжиною алелів в індивідуальному генотипі, виражених у тандемних повторах) також суттєво варіювала для окремих локусів МС-ДНК. Найменшу оцінку цей показник мав для локусу $E T H 3\left(d^{2}=4,81 \pm 0,76\right)$, а найбільшу - для локусу TGLA122 $\left(d^{2}=31,90 \pm 3,70\right)$ (див. табл. 6).

Таблиця 6

Кількість гомозиготних (Nhom) та гетерозиготних (Nhet) телиць ПМП, оцінки фактичної гетерозиготності $(S L H)$ та середнього квадрату різниці між алелями в індивідуальному генотипі (міра $d^{2}$ ) для 10 локусів МС-ДНК

\begin{tabular}{|c|c|c|c|c|}
\hline Локус & 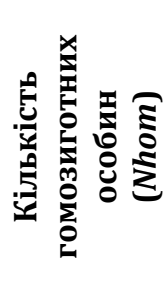 & 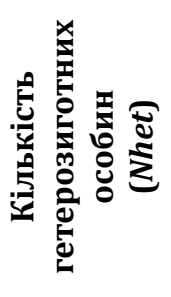 & 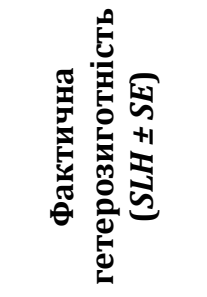 & 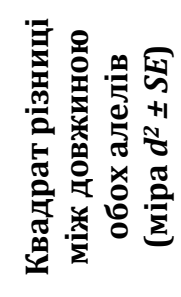 \\
\hline TGLA227 & 54 & 92 & $0,630 \pm 0,040$ & $20,47 \pm 2,52$ \\
\hline$B M 2113$ & 41 & 150 & $0,785 \pm 0,030$ & $16,34 \pm 1,40$ \\
\hline TGLA53 & 62 & 45 & $0,421 \pm 0,048$ & $5,83 \pm 1,10$ \\
\hline ETH10 & 38 & 154 & $0,802 \pm 0,029$ & $8,19 \pm 0,78$ \\
\hline SPS115 & 54 & 138 & $0,719 \pm 0,032$ & $5,17 \pm 0,48$ \\
\hline TGLA122 & 40 & 152 & $0,792 \pm 0,029$ & $31,90 \pm 3,70$ \\
\hline INRA023 & 47 & 145 & $0,755 \pm 0,031$ & $24,81 \pm 2,16$ \\
\hline BM1818 & 34 & 155 & $0,820 \pm 0,028$ & $6,04 \pm 0,57$ \\
\hline ETH3 & 93 & 75 & $0,446 \pm 0,038$ & $4,81 \pm 0,76$ \\
\hline BM1824 & 81 & 111 & $0,578 \pm 0,036$ & $5,36 \pm 0,79$ \\
\hline
\end{tabular}


Характерно, що для вивчених локусів МС-ДНК можна виділити окремі патерни залежно від характеру розподілу за оцінками абсолютної різниці між довжиною алелів в індивідуальному генотипі (IDA) телиць ПМП. Так, для локусів ETH10 та BM1824 характерно переважання гетерозиготних генотипів, що відрізняються лише одним тандемним повтором (рис. ЗА). Для локусів BM1818 та ETH3 переважають гетерозиготні генотипи, що відрізняються двома тандемними повторами (рис. 3В). Для локусів SPS115, TGLA122 та TGLA53 відмічається наявність двох піків, що відповідають різниці у один та чотири тандемних повтори (рис. $3 \mathrm{C}$ ), а для локусів TGLA227 та INRAO23 - трьох піків, що відповідають трьом, шести та 10 тандемним повторам (рис. 3D).

Характерно, між оцінками фактичної гетерозиготності $(S L H)$ в розрізі окремих локусів та відповідними оцінками міри $d^{2}$ кореляція відсутня (коефіцієнт рангової кореляції Спірмена: $R s=0,503$; $P=0,138)$, що може свідчить про те, що обидва підходи відображують різні та незалежні характеристики локусів МС-ДНК.
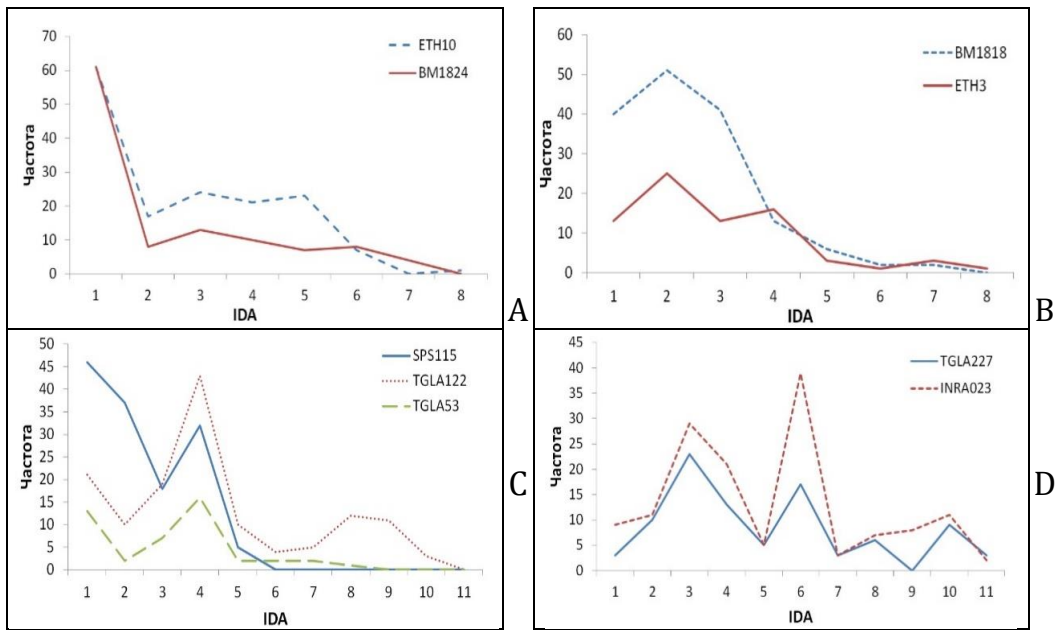

Рис. 3. Розподіл за оцінками абсолютної різниці між довжиною алелів (у тандем них повторах) в індивідуальному генотипі (IDA) телиць ПМП для різних локусів МС-ДНК:

A - ETH10 та BM1824; В - BM1818 та ETH3; C - SPS115, TGLA122 Ta TGLA53; D - TGLA227 та INRA023. 
Результати двофакторного дисперсійного аналізу підтвердили наявність вірогідного впливу фактору «підтип» на живу масу телиць ПМП в різному віці (у всіх випадках: $P>0,05$ ). Аналіз впливу генотипу особини (гомо- чи гетерозиготний) не залежно від підтипу, до якого вона відноситься, свідчить, що лише у двох випадках була виявлена вірогідна різниця. Це стосується впливу локусу BM2113 на живу масу телиць у віці 15 міс. та впливу локусу BM1818 на живу масу телиць у віці 8 міс. (табл. 7).

Таблиця 7

Вплив генотипу за локусами МС-ДНК на показники мінливості $($ Mean $\pm S E)$ живої маси телиць ПМП в різному віці, кг

\begin{tabular}{|c|c|c|c|}
\hline \multirow{2}{*}{ Локус } & \multirow{2}{*}{ Ознака } & \multicolumn{2}{|c|}{ Генотип } \\
\cline { 3 - 4 } & & гомозиготний & гетерозиготний \\
\hline$B M 2113$ & $\mathrm{~W} 15$ & $310,9 \pm 15,8(\mathrm{n}=10)$ & $269,3 \pm 6,1^{* *}(\mathrm{n}=49)$ \\
\hline$B M 1818$ & $\mathrm{~W} 8$ & $171,8 \pm 12,8(\mathrm{n}=8)$ & $198,3 \pm 4,3^{*}(\mathrm{n}=59)$ \\
\hline
\end{tabular}

При цьому, для локусу ВM2113 гомозиготні особини вірогідно переважали особин із гетерозиготним генотипом $(310,9 \pm 15,8$ та 269,3 \pm 6,1 кг у віці 15 міс., відповідно); з іншого боку, для локусу BM1818, навпаки, особини із гетерозиготним генотипом вірогідно переважали гомозигот $(198,3 \pm 4,3$ та $171,8 \pm 12,8$ кг у віці 8 міс., відповідно). Більш інформативними були результати аналізу сумісного впливу підтипу та генотипу за 10 локусами МС-ДНК на ознаки живої маси телиць ПМП в різному віці (табл. 8).

Таблиця 8

Оцінка сумісного впливу підтипу та генотипу за 10 локусами МС-ДНК на ознаки живої маси телиць ПМП в різному віці

\begin{tabular}{|c|c|c|c|c|c|c|}
\hline \multirow{2}{*}{ Локус } & \multicolumn{7}{|c|}{ Ознака } \\
\cline { 2 - 7 } & $\mathbf{W B}$ & $\mathbf{W W}$ & $\mathbf{W 8}$ & $\mathbf{W 1 2}$ & $\mathbf{W 1 5}$ & $\mathbf{W 1 8}$ \\
\hline TGLA227 & $\mathrm{ns}$ & $\mathrm{ns}$ & $\mathrm{ns}$ & $\mathrm{ns}$ & $\mathrm{ns}$ & $\mathrm{ns}$ \\
\hline BM2113 & $*$ & $\mathrm{~ns}$ & $\mathrm{~ns}$ & $\mathrm{~ns}$ & $\mathrm{~ns}$ & $\mathrm{~ns}$ \\
\hline TGLA53 & $*$ & $\mathrm{~ns}$ & $\mathrm{~ns}$ & $\mathrm{~ns}$ & $\mathrm{~ns}$ & $\mathrm{~ns}$ \\
\hline$E T H 10$ & $\mathrm{~ns}$ & $\mathrm{~ns}$ & $\mathrm{~ns}$ & $\mathrm{~ns}$ & $\mathrm{~ns}$ & $*$ \\
\hline SPS115 & $\mathrm{ns}$ & $*$ & $\mathrm{~ns}$ & $*$ & $*$ & $\mathrm{~ns}$ \\
\hline TGLA122 & $\mathrm{ns}$ & $\mathrm{ns}$ & $*$ & $\mathrm{~ns}$ & $*$ & $\mathrm{~ns}$ \\
\hline INRA023 & $\mathrm{ns}$ & $\mathrm{ns}$ & $\mathrm{ns}$ & $\mathrm{ns}$ & $\mathrm{ns}$ & $\mathrm{ns}$ \\
\hline BM1818 & $\mathrm{ns}$ & $\mathrm{ns}$ & $\mathrm{ns}$ & $\mathrm{ns}$ & $\mathrm{ns}$ & $\mathrm{ns}$ \\
\hline$E T H 3$ & $\mathrm{~ns}$ & $\mathrm{~ns}$ & $\mathrm{~ns}$ & $\mathrm{~ns}$ & $*$ & $*$ \\
\hline BM1824 & $*$ & $\mathrm{~ns}$ & $\mathrm{~ns}$ & $\mathrm{~ns}$ & $*$ & $\mathrm{~ns}$ \\
\hline
\end{tabular}


Лише для локусів TGLA227, BM1818 та INRA023 не було виявлено жодного випадку асоціації із живою масою телиць ПМП. Для решти локусів МС-ДНК такі випадки було зафіксовано від одного до трьох разів. В найбільшому ступені вірогідний вплив гетерозиготності за локусами МС-ДНК на їх живу масу було відмічено при народженні та у віці 15 міс. (див. табл. 8).

Вірогідний сумісний вплив, виявлений нами при аналізі, свідчить про те, що різниця між гомо- та гетерозиготними особинами відрізняється (як за величиною, так й за рівнем вірогідності) серед телиць різних підтипів (табл.9). Так, наприклад, асоціація між гетерозиготністю за локусом ВM2113 та живою масою при народженні мала місце для особин низькровного підтипу $(25,6 \pm 0,8$ кг для гомозиготних та 23,2 $\pm 0,5$ кг для гетерозиготних генотипів, відповідно). Серед особин висококровного підтипу вірогідна різниця була відсутня. При наявності вірогідного впливу локусу мали місце як випадки переважання гомозиготних генотипів над гетерозиготними, так й переважання гетерозиготних генотипів над гомозиготними (див. табл. 9).

В табл. 10 наведено оцінки коефіцієнтів рангової кореляції Спірмена між живою масою телиць ПМП в різному віці та індивідуальними оцінками середнього квадрату різниці між алелями в індивідуальному генотипі (міра $d^{2}$ ) для 10 локусів МС-ДНК.

Таблиця 9

Вплив генотипу за локусами МС-ДНК та підтипу на показники мінливості $(M e a n \pm S E)$ живої маси телиць ПМП в різному віці, кг

\begin{tabular}{|c|c|c|c|c|c|}
\hline \multirow{2}{*}{ Локус } & \multirow{2}{*}{ Ознака } & \multicolumn{2}{|c|}{$\begin{array}{c}\text { Низьокровний (НК) } \\
\text { підтип }\end{array}$} & \multicolumn{2}{|c|}{$\begin{array}{c}\text { Висококровний (ВК) } \\
\text { підтип }\end{array}$} \\
\cline { 3 - 6 } & $\begin{array}{c}\text { зиготний } \\
\text { генотип }\end{array}$ & $\begin{array}{c}\text { Гетеро- } \\
\text { зиготний } \\
\text { генотип }\end{array}$ & $\begin{array}{c}\text { Гомо- } \\
\text { зиготний } \\
\text { генотип }\end{array}$ & $\begin{array}{c}\text { Гетеро- } \\
\text { зиготний } \\
\text { генотип }\end{array}$ \\
\hline BM2113 & WB & $\begin{array}{c}25,6 \pm 0,8 \\
(\mathrm{n}=9)\end{array}$ & $\begin{array}{c}23,2 \pm 0,5^{*} \\
(\mathrm{n}=27)\end{array}$ & $\begin{array}{c}20,0 \pm 1,7 \\
(\mathrm{n}=3)\end{array}$ & $\begin{array}{c}21,9 \pm 0,5 \\
(\mathrm{n}=35)\end{array}$ \\
\hline SPS115 & WW & $\begin{array}{c}204,7 \pm 14,9 \\
(\mathrm{n}=7)\end{array}$ & $\begin{array}{c}190,6 \pm 5,5 \\
(\mathrm{n}=25)\end{array}$ & $\begin{array}{c}151,2 \pm 8,9 \\
(\mathrm{n}=13)\end{array}$ & $\begin{array}{c}177,7 \pm 6,1^{* *} \\
(\mathrm{n}=25)\end{array}$ \\
\hline TGLA122 & W8 & $\begin{array}{c}188,7 \pm 11,3 \\
(\mathrm{n}=9)\end{array}$ & $\begin{array}{c}212,6 \pm 5,9 * \\
(\mathrm{n}=22)\end{array}$ & $\begin{array}{c}195,6 \pm 10,8 \\
(\mathrm{n}=10)\end{array}$ & $\begin{array}{c}184,5 \pm 6,7 \\
(\mathrm{n}=28)\end{array}$ \\
\hline
\end{tabular}


Таблиця 10

Коефіцієнти рангової кореляції Спірмена між живою масою телиць ПМП в різному віці та індивідуальними оцінками середнього квадрату різниці між алелями в індивідуальному генотипі (міра $d^{2}$ ) для 10 локусів МС-ДНК

\begin{tabular}{|c|c|c|}
\hline \multirow{2}{*}{ Локус } & \multicolumn{2}{|c|}{ Підтип } \\
\cline { 2 - 3 } & $\begin{array}{c}\text { низькокровний } \\
(\boldsymbol{n}=\mathbf{3 6})\end{array}$ & $\begin{array}{c}\text { висококровний } \\
(\boldsymbol{n}=\mathbf{3 8})\end{array}$ \\
\hline TGLA227 & $\mathrm{ns}$ & $\mathrm{ns}$ \\
\hline BM2113 & $\mathrm{WB}\left(-0,432^{* *}\right)$ & $\mathrm{W} 15\left(-0,333^{*}\right)$ \\
\hline TGLA53 & $\mathrm{ns}$ & $\mathrm{ns}$ \\
\hline$E T H 10$ & $\mathrm{~ns}$ & $\mathrm{WW}\left(0,369^{*}\right) ; \mathrm{W} 8\left(0,353^{*}\right) ;$ \\
\hline & & $\mathrm{W} 12\left(0,374^{*}\right) ; \mathrm{W} 15\left(0,443^{*}\right)$ \\
SPS115 & $\mathrm{ns} 18\left(0,420^{*}\right)$ \\
& $\mathrm{ns}$ & $\mathrm{ns}$ \\
\hline TGLA122 & $\mathrm{ns}$ & $\mathrm{ns}$ \\
\hline$I N R A 023$ & $\mathrm{~ns}$ & $\mathrm{~ns}$ \\
\hline$B M 1818$ & $\mathrm{WW}\left(0,404^{*}\right)$ & $\mathrm{ns}$ \\
\hline$E T H 3$ & $\mathrm{~ns}$ \\
\hline$B M 1824$ & $\mathrm{WB}\left(-0,353^{*}\right) ; \mathrm{W} 15\left(0,462^{*}\right)$ & $\mathrm{ns}$ \\
\hline
\end{tabular}

Примітка: Наведено лише вірогідні оцінки коефіцієнту рангової кореляції Спірмена.

Для чотирьох локусів MC-ДНК (BM2113, SPS115, ETH3 та BM1824) було встановлено наявність асоціації між живою масою телиць ПМП та ступенем прояву гетерозиготності. При цьому, для трьох останніх асоціацію було відмічено лише для телиць одного підтипу (або низько-, або висококровного) і лише для локусу ВM2113 ця асоціація мала місце у тварин обох підтипів (див. табл. 10).

Найбільш суттєвий зв'язок із індивідуальною мірою $d^{2}$ було відмічено серед тварин висококровного підтипу у відношенні локусу SPS115. В цьому випадку вірогідні оцінки коефіцієнту рангової кореляції Спірмена було отримано для всіх фенотипових ознак, крім живої маси при народженні. У розрізі окремих ознак, в найбільшому ступені зв'язок між мірою $d^{2}$ було відмічено для живої маси при народженні, при відлученні та у віці 15 міс. (див. табл. 10), що співпадає із результатами, отриманими раніше при аналізі впливу типу генотипу (гомо- чи гетерозиготний) (див. табл. 8).

Виявлені зв'язки у більшості випадків мали позитивний знак, тобто, чим більше різниця між довжиною алелів в межах індивідуального генотипу, тим вище жива маса телиць. Особливо, це 
характерно для локусу SPS115, а також для локусів ETH3 та BM1824. Негативний знак асоціації між мірою $d^{2}$ та живою масою при народженні (серед тварин низькокровного підтипу) та у віці 15 міс. (серед тварин висококровного підтипу) було виявлено для локусу BM2113. Нарешті, для локусу ВM1824 відмічено зміну знаку в онтогенезі 3 негативного (для живої маси при народженні) на позитивний (для живої маси у віці 15 міс.). Таким чином, нами було встановлено наявність зв'язку між двома різними формами гетерозиготності та живою масою телиць ПМП, але прояв та напрямок цього зв'язку не співпадав у розрізі окремих локусів МС-ДНК.

На рис. 4 наведено розподіл за оцінками мультилокусної гетерозиготності $(M L H)$ для телиць ПМП та середнього квадрату різниці між алелями в індивідуальному генотипі (міра mean $d^{2}$ ) для 10 локусів МС-ДНК. В обох випадках розподіл мав асиметричну форму із довгим «хвостом» у бік низьких значень для $M L H$ та у бік високих значень для міри mean $d^{2}$.

В межах окремих особин оцінки мультилокусної гетерозиготності $(M L H)$ варіювали від 0,300 до 1,000 із середнім значенням $0,685 \pm 0,011$, а оцінки міри теап $d^{2}$ варіювали від 1,57 до 39,11 із середнім значенням $13,16 \pm 0,56$ тандемних повторів 2 . Встановлено наявність вірогідного та позитивного зв'язку між індивідуальними оцінками $M L H$ та міри mean $d^{2}(r=0,363 ; P<0,001)$.

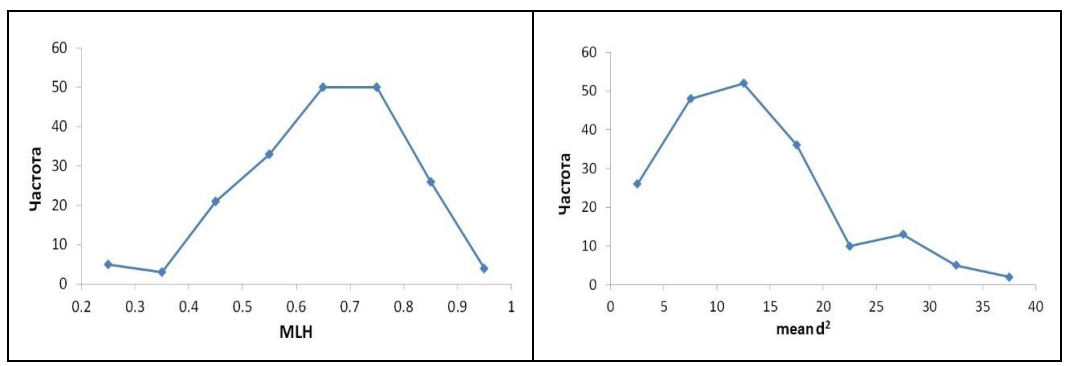

A

B

Рис. 4. Розподіл за оцінками мультилокусної гетерозиготності (MLH) для телиць ПМП (А) та середнього квадрату різниці між алелями в індивідуальному генотипі (міра mean $d^{2}$ ) для 10 локусів МС-ДНК (В)

Вірогідний вплив градації за $M L H$ на живу масу телиць ПМП було встановлено лише для живої маси тварин низькокровного підтипу 
при народженні $\left(F_{5} ; 0=2,57 ; P=0,047\right)$ та у віці 12 міс. $\left(F_{5} ; 25=3,05\right.$; $P=0,028)$. При цьому, характер зв'язку між індивідуальними оцінками $M L H$ та живою масою змінюється у ході онтогенезу. При народженні телиці із найнижчою живою масою характеризувалися близькими до середньої оцінками $M L H$ (рис. 5A), а у віці 12 міс., навпаки, тварини із оцінками мультилокусної гетерозиготності у межах 0,60-0,90 мали найвищу живу масу (рис. 5B).

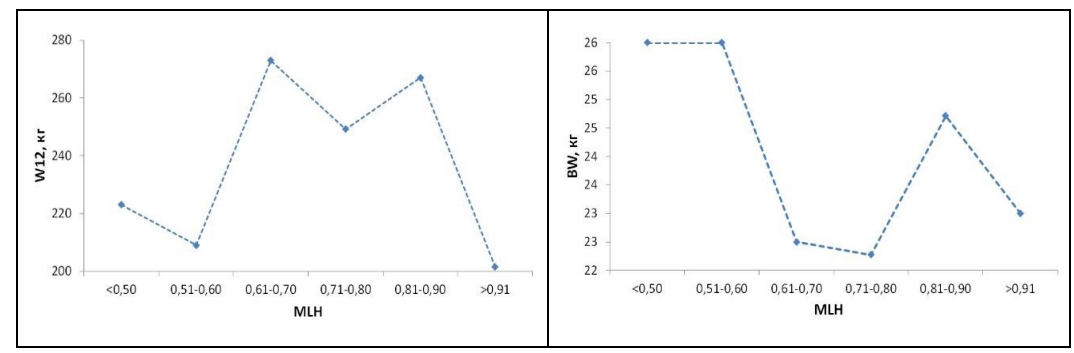

A B

Рис. 5. Вплив середньої мультилокусної гетерозиготності (MLH) для 10 локусів МС-ДНК на живу масу телиць ПМП низькокровного підтипу при народженні (A) та у віці 12 міс. (B)

У відношенні оцінок середнього квадрату різниці між алелями в індивідуальному генотипі (міра mean $d^{2}$ ) нами вірогідних зв'язків із живою масою телиць ПМП в різному віці не встановлено. Доведено, що відповідні оцінки вірогідно відрізнялися $\left(F_{5} ; 4=2,54 ; P=0,041\right)$ у тварин різних підтипів для живої маси у віці 15 міс. (рис. 6).

Так, для телиць низькокровного підтипу, які мали оцінку міри mean $d^{2}$ в межах 15,1-20,0 тандемних повторів ${ }^{2}$, жива маса у віці 15 міс. була найвищою, а телиці висококровного підтипу 3 аналогічними оцінками міри mean $d^{2}$, навпаки, мали найнижчу живу масу в цьому віці (див. рис. 6).

\section{3. Обговорення}

В нашому дослідженні було встановлено, що ознаки відтворення (багатоплідність при народженні та відлученні, а також кількість/частка мертвонароджених поросят у гнізді) були вищими (для мертвонародження, відповідно, нижчими) серед свиноматок ВБП, що мали гомозиготний генотип за більшістю використаних в 
аналізі локусів МС-ДНК (див. табл. 2). Таким чином, кореляція між гетерозиготністю та ознаками відтворення мала негативний знак, тобто, ми маємо справу с проявом негативних випадків HFCs. Лише для локусу $S w 857$ зростання оцінок міри $d^{2}$ призводило до збільшення загальної кількості поросят при народженні протягом I-II-го опоросів (табл. 3), що свідчить про прояв позитивних випадків HFCs.

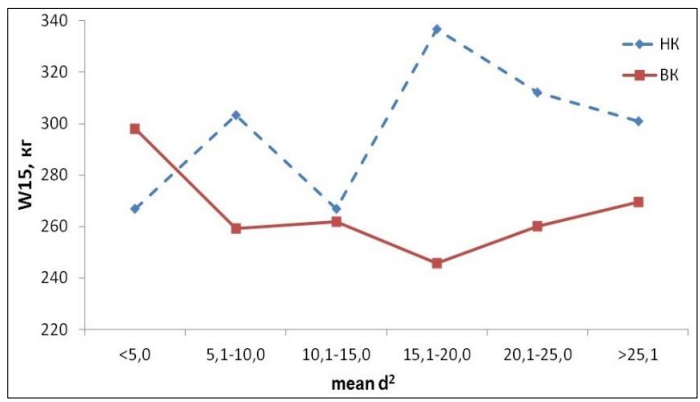

\section{Рис. 6. Вплив підтипу та оцінок середнього квадрату різниці між алелями в індивідуальному генотипі $\left(\right.$ mean $\left.d^{2}\right)$ для 10 локусів МС-ДНК на живу масу телиць ПМП у віці 15 міс.}

Одночасне існування в популяції позитивних та негативних випадків кореляції між гетерозиготністю (за різними генетичними маркерами) та компонентами виживаності раніше вже було показано при дослідженні популяції колючки триголкової (Gasterosteus aculeatus) із естуарію р. Святого Лаврентія (Канада) [20]. Різний напрямок HFCs може бути також пов'язаний із типом генетичного маркера. При дослідженні синиці блакитної (Cyanistes caeruleus) із Австрії було показано, що вплив MLH на виживаність за нейтральними та функціональними локусами мав різний напрямок [30]. Негативний вплив функціональних локусів краще пояснювався локальними ефектами, а позитивний вплив нейтральних маркерів міг відображати ефект інбридингу в популяції. Тому, негативні HFCs можуть бути проявом впливу окремих локусів чи аутбредної депресії. При цьому, щоб HFC відображала вплив аутбридингу, мультилокусна гетерозиготність, виміряна за допомогою МС-ДНК локусів, повинна відображати гетерозиготність загального геному та рівень індивідуального інбридингу (або аутбридингу) [30]. 
В переважній більшості робіт, де розглядався вплив різних оцінок гетерозиготності (коефіцієнт інбридингу, гетерозиготність та оцінки міри $d^{2}$ як для окремих структурних генів та локусів МС-ДНК, так й їх мультилокусна оцінка) на ознаки тварин, які розводяться в штучних умовах найчастіше відмічалось переважання гетерозиготних особин над гомозиготними. Хоча у випадку тилапії було встановлено, що особини, гомозиготні за локусом UNH146, переважали гетерозигот за довжиною та масою тіла [7].

Для природних популяцій прояв негативних випадків HFCs не рідкість, хоча вони реєструється значно рідше, ніж випадки позитивного зв'язку між гетерозиготністю та компонентами пристосованості [9]. Крім того, негативні випадки HFCs частіше реєструвалися при аналізі малочислених вибірок та при використанні оцінок mean $d^{2}$ [9], що також підтверджується отриманими нами результатами.

Доведено, що залежність між оцінками гетерозиготності та компонентами пристосованості (в т.ч., й ознаками відтворення) має криволінійну форму, як це було показано при дослідженні окуня синьозябрового (Lepomis macrochirus) в озері Opinicon (Канада) [28]. Таким чином, можна очікувати, що пристосованість буде збільшуватися із зростанням рівня гетерозиготності особин, але після досягнення максимуму буде вже знижуватися при подальшому зростанню рівня гетерозиготності. Отримані нами результати (див. рис. 1А) повністю узгоджуються з цією гіпотезою, враховуючи, що особини з низькими індивідуальними оцінками мультилокусної гетерозиготності в дослідженій вибірці свиноматок (із СГПП «Техмет-Юг») були не чисельні й, відповідно, ліва частина цієї залежності $є$ «обрізаною».

Дійсно, більшість досліджень, що відмічали вірогідні випадки HFCs, вказували на лінійний, позитивний зв'язок між мірами індивідуальної гетерозиготності та ознаками, що пов'язані із пристосованістю, тобто, більш високий рівень гетерозиготності мав позитивний прояв [9]. Рідше відмічався негативний вплив гетозиготності, що може бути проявом криволінійного зв'язку між гетерозиготністю та ознаками, тобто, особини із проміжним рівнем гетерозиготності мали перевагу над особинами із дуже низьким, чи дуже високим рівнем гетерозиготності [26; 28; 29].

3 іншого боку, в господарстві СГПП «Техмет-Юг» використовувались дві групи тварин, які відрізняються за походженням свині англійської та угорської селекції. Більшість тварин, яких було 
досліджено, $\epsilon$ різними варіантами схрещування між ними $\left(\mathrm{F}_{1}, \mathrm{~F}_{2}, \mathrm{BC}_{1}\right.$ та ін.). У таких помісних тварин може проявлятися порушення генних комплексів, що були сформовані внаслідок тривалої селекційної роботи із кожною групою плідників, результатом якого і $\epsilon$ аутбредна депресія, що супроводжувалась зниженням ознак відтворення при схрещуванні дуже генетично віддалених особин (див. рис. 2В).

Крім того, висока гетерозиготність може бути пов'язана зі зниженням пристосованості в ситуаціях, коли діє аутбредна депресія, але це вимагає схрещування між локально адаптованими популяціями [31], якими в нашому випадку є групи племінних тварин різного походження - англійської та угорської селекції, відповідно. В роботі [5] відмічено наявність суттєвих відмінностей щодо особливостей терморегуляції організму свиней угорської та англійської селекції в умовах півдня України. Крім того, помісні тварини, які є результатом схрещування свиней англійської та угорської селекції вірогідно поступалися за середньодобовим приростом та довжиною напівтуші ровесницям, які мали батьками лише тварин угорської селекції [1]. Характерно, що в ТОВ «Таврійські свині» використовувалися лише свині великої білої породи англійської селекції.

Встановлені нами вірогідні зв'язки між індивідуальними оцінками гетерозиготності свиноматок ВБП за локусами МС-ДНК та ознаками відтворення мали місце лише протягом III-го опоросу, тобто, віку, коли багатоплідність свиноматок досягає свого максимуму. Раніше, при досліджені альпійського козла (Capra ibex) також було встановлено, що вплив MLH мав віково-специфічний характер [37].

Крім того, елементи штучного відбору (індивідуальне вибракування) можуть бути відповідальними за формування негативних випадків HFCs. $€$ висока ймовірність того, що після I-го та II-го опоросів були вибракувані свиноматки, більшість яких мала низькі показники багатоплідності та оцінки гетерозиготності одночасно, що й призвело до формування негативного зв'язку у свиноматок протягом III-го опоросу. Підтвердженням цієї гіпотези $\epsilon$ той факт, що оцінки коефіцієнту рангової кореляції $(R s)$ між гетерозиготністю та ознаками багатоплідності серед всіх першоопоросок були невірогідними. Але, якщо при розрахунках не враховувалися першоопороски, яких було потім вибракувано, то відповідні оцінки коефіцієнту рангової кореляції $(R s)$ ставали 
вірогідними $(P<0,05)$ та мали негативний знак. Аналогічну ситуацію було відмічено раніше при досліджені тетерука євразійського (Lyrurus tetrix). Було показано [35], що до відбору загальний зв'язок із пристосованістю самиць формував позитивні HFCs. Однак, після того, як відбір за життєздатністю елімінував 3 популяції самиць з низькою гетерозиготністю та випадкову вибірку інших самиць (біля 20 \%), загальний зв'язок мав негативний знак.

Для популяції антільської горлиці (Zenaida aurita) на о-ві Барбадос було встановлено наявність вірогідної негативної кореляції між індивідуальними оцінками MLH та станом тіла (body condition) серед ювенільних особин (тобто, гомозиготні особини мали кращі показники оцінки стану тіла, ніж гетерозиготні), що свідчить про прояв аутбредної депресії. Серед дорослих особин така закономірність була відсутня [27].

Було встановлено, що у свійських та сільськогосподарських тварин гетерозиготність вірогідно впливала на проміри тіла [6; 7; 11], репродуктивні ознаки [19], якість м'яса [22], вміст жиру в молоці [18], стійкість до паразитів [24] та хвороб [12; 34; 36]. Але найчастіше було встановлено наявність певної асоціації між показниками гетерозиготності із живою масою та їх приростами [15; 16; 21; 38; 39], що було відмічено й в нашому дослідженні. Так, для телиць ПМП нами було доведено вірогідний вплив локусу BM2113 на живу масу у віці 15 міс. та локусу BM1818 на живу масу у віці 8 міс. (див. табл.7). В розрізі різних підтипів для більшості локусів МС-ДНК зв'язок між локусами МС-ДНК було відмічено для живої маси при народженні та у віці 15 міс. (див. табл. 8). Характерно, що раніше [3] нами було встановлено три алеля (BM1824178, TGLA22783, BM1818258), наявність яких в генотипі телиць ПМП забезпечувала більш інтенсивний ріст живої маси та один алель (BM2113141), що пов'язаний із повільним зростанням живої маси у різні вікові періоди.

Наявність вірогідних зв'язків між ознаками та гетерозиготністю за окремими локусами МС-ДНК раніше вже було доведено для різних тварин. Так, гетерозиготність за локусом UNH146 впливала на довжину тіла та живу масу прісноводної тилапії (Oreochromis spp.) [7], гетерозиготність за локусами INRA111 та BMS2847 була пов'язана зі стійкістю свійської худоби до туберкульозу [12], а гетерозиготність за локусом ВMC5221 - із стійкістю до копитної гнилі у овець [34; 36]. 
При цьому, як і в нашому випадку, цей зв'язок не завжди демонструє перевагу особин із гетерозиготним генотипом над гомозиготами, що можна було б очікувати, виходячи з теорії гетерозису. Перевагу гомозиготних особин над гетерозиготами було відмічено, наприклад, для довжини тіла тилапії [7]. 3 іншого боку, вівці гомозиготні за локусом ВMC5221 характеризувалися підвищеним ризиком захворіти на копитну гниль, а в групі тварин, де цю хворобу не було виявлено, навпаки, спостерігався дуже значний дефіцит гомозигот за цим локусом [34; 36].

Аналогічна ситуація мала місце і у відношенні зв'язку індивідуальних оцінок мультилокусної гетерозиготності $(M L H)$ із ознаками продуктивності. Встановлено [38], що для свиней оцінки $M L H$, що були отримані для 56 локусів МС-ДНК, розташованих на 1-й, 2-й, 11-й, 13-й, 17-й та 18-й хромосомах (т.зв. геномна гетерозиготність, genomic heterozygosity), вірогідно та позитивно пов'язані з забійною масою та середньодобовими приростами живої маси тварин, хоча при цьому зв'язок із товщиною шпику був відсутній. Оцінки $M L H$, розраховані для 15 локусів MC-ДНК, були вірогідно та негативно пов'язані із кількістю легеневих гельмінтів (Protostrongylus spp.) у диких баранів-товсторогів [24]. Також були відмічені вірогідні асоціації між індивідуальними оцінками мультилокусної гетерозиготності та живою масою, висотою у холці, довжиною тіла, обхватом грудей та обхватом п'ястка у кіз породи Tongshan Black-boned [15].

В цілому, зв'язок геномної гетерозиготності з ознаками варіює від хромосоми до хромосоми, а асоціація між гетерозиготністю та продуктивністю носить скоріше нелінійний комплексний характер внаслідок складної взаємодії між окремими генами [38].

Вірогідний зв'язок також мав місце між середньою мультилокусною оцінкою міри $d^{2}$ та певними промірами тіла кобил породи Lipizzan [11]. 3 іншого боку, вірогідної кореляції між оцінками міри $d^{2}$ та живою масою курей відмічено не було [21], як й в нашому дослідженні.

Існують також підтвердження гіпотези про те, що зараження паразитами та чутливість до хвороб може бути наслідком зниженої гетерозиготності у популяціях диких та свійських тварин, а деякі окремі локуси можуть обумовлювати стійкість до паразитів та хвороб $[12 ; 24 ; 34]$. Також, індивідуальний рівень гетерозиготності може бути використано у якості прогностичної ознаки при аналізі ростових процесів сільськогосподарських тварин [15]. Важливою 
перевагою цього підходу є те, що він може бути використаний вже на ранніх етапах онтогенезу [6].

Таким чином, використання моделей, що включають оцінки гетерозиготності, призводить до більш точного відбору ремонтних тварин для селекційних цілей, що може збільшити генетичний приріст ознак продуктивності, ймовірно, внаслідок домінантної дії окремих генів [16].

\section{Висновки}

Нами було встановлено переважання особин із гомозиготним генотипом над гетерозиготним у відношенні показників багатоплідності та, відповідно, протилежну картину у відношенні кількості та частки мертвонароджених поросят у гнізді. В найбільшому ступені це було характерно для особин СГПП «Техмет-Юг». Таким чином, кореляція між гетерозиготністю та ознаками відтворення мала негативний знак, тобто, ми мали справу с проявом негативних випадків HFCs. Ми робимо висновок, що слід бути обережним при схрещуванні племінних тварин різного походження (англійської та угорської селекції), щоб уникнути аутбредної депресії.

Аналіз впливу генотипу телиць ПМП (гомо- чи гетерозиготний) не залежно від підтипу, до якого вони відносяться, свідчить, що лише у двох випадках було виявлено вірогідну різницю. Це стосується впливу локусу BM2113 на живу масу телиць у віці 15 міс. та впливу локусу BM1818 на живу масу телиць у віці 8 міс. Для чотирьох локусів МС-ДНК (BM2113, SPS115, ETH3 та BM1824) було встановлено наявність асоціації між живою масою телиць ПМП та ступенем прояву гетерозиготності. Найбільш суттєвий зв'язок 3 індивідуальною мірою $d^{2}$ було відмічено серед тварин висококровного підтипу у відношенні локусу SPS115. У розрізі окремих ознак, в найбільшому ступені зв'язок між мірою $d^{2}$ було відмічено для живої маси при народженні, при відлученні та у віці 15 міс. В цілому, оцінки індивідуальної гетерозиготності для 10 локусів MC-ДНК та середні мультилокусні оцінки $d^{2}$ були слабко пов'язані із живою масою телиць південної м'ясної породи.

Таким чином, характер зв'язку між гетерозиготністю та продуктивністю серед досліджених груп свиней та худоби в значній мірі залежав як від походження тварин, так і напряму селекційноплемінної роботи в господарствах.

Подяки. Робота виконана в рамках фінансування за держбюджетними тематиками Міністерства освіти і науки України (номера 
державної реєстрації - 0119U001042 та 0121U109492). Автори висловлюють подяку керівництву та фахівцям ТОВ «Таврійські свині» Херсонської області, СГПП «Техмет-Юг» Миколаївської області та ДП «ДГ Асканійське» Асканійської державної сільськогосподарської дослідної станції Інституту зрошуваного землеробства НААН Каховського району Херсонської області.

\section{Список використаних джерел:}

1. Кислинская А. И. Откормочные и мясные качества чистопородного молодняка свиней крупной белой породы венгерской селекции и их помесей в постадаптационный период. Вестник Красноярского государственного аграрного университета. 2013. T. 10. C. 167-171.

2. Крамаренко О.С. Оцінювання генетичної структури та прогнозування продуктивності тварин південної м'ясної породи за ДНК-маркерами : монографія. Миколаїв : Іліон, 2017. 166 с.

3. Крамаренко О. С., Сухоручко Т. О., Крамаренко С. С. Поліморфізм та асоціація STR-локусів з ознаками росту телиць південної м'ясної породи. Таврійський науковий вісник. 2020. № 113. C. 181-192.

4. Крамаренко С. С., Луговий С. І., Лихач А. В., Крамаренко О. С. Аналіз біометричних даних у розведенні та селекції тварин : навчальний посібник. Миколаїв : МНАУ, 2019. 226 с.

5. Кислинська А. І. Терморегуляція організму свиней імпортної популяції в процесі адаптації на півдні України. Таврійський науковий вісник. Серія: Сільськогосподарські науки. 2012. Вип. № 78, ч. 2 (1). C. 76-81.

6. Agatep R. C. Microsatellite loci heterozygosity and fitness correlations among three genetic groups of domesticated mallard ducks (Anas platyrhynchos domesticus L.) in the Philippines. Journal of Agricultural Technology. 2015. Vol. 11(7). P. 1439-1447.

7. Appleyard S. A., Renwick J. M., Mather P. B. Individual heterozygosity levels and relative growth performance in Oreochromis niloticus (L.) cultured under Fijian conditions. Aquaculture Research. 2001. Vol. 32(4). P. 287-296.

8. Bjelland D.W., Weigel K.A., Vukasinovic N., Nkrumah J.D. Evaluation of inbreeding depression in Holstein cattle using wholegenome SNP markers and alternative measures of genomic inbreeding. Journal of Dairy Science. 2013. Vol. 96(7). P. 4697-4706. 
9. Chapman J. R., Nakagawa S., Coltman D. W., Slate J., Sheldon B. C. A quantitative review of heterozygosity-fitness correlations in animal populations. Molecular Ecology. 2009. Vol. 18(13). P. 2746-2765.

10. Coulson T. N., Pemberton J. M., Albon S. D., Beaumont M., Marshall T. C., Guinness F. E., Clutton-Brock T. H. Microsatellites reveal heterosis in red deer. Proceedings of the Royal Society of London. Series B: Biological Sciences. 1998. Vol. 265(1395). P. 489-495.

11. Curik I., Zechner P., Sölkner J., Achmann R., Bodo I., Dovc P., Kavar T., Marti E., Brem G. Inbreeding, microsatellite heterozygosity, and morphological traits in Lipizzan horses. Journal of Heredity. 2003. Vol. 94(2). P. 125-132.

12. Driscoll E. E., Hoffman J. I., Green L. E., Medley G. F., Amos W. A preliminary study of genetic factors that influence susceptibility to bovine tuberculosis in the British cattle herd. PLoS One. 2011. Vol. 6(4). e18806.

13. Frankham R., Ballou J. D., Eldridge M. D., Lacy R. C., Ralls K., Dudash M. R., Fenster C. B. Predicting the probability of outbreeding depression. Conservation Biology. 2011. Vol. 25(3). P. 465-475.

14. González-Recio O., De Maturana E. L., Gutiérrez J. P. Inbreeding depression on female fertility and calving ease in Spanish dairy cattle. Journal of Dairy Science. 2007. Vol. 90(12). P. 5744-5752.

15. Han Y. G., Liu G. Q., Jiang X. P., Liang G. M., He C. B., Wang D. W., $\mathrm{Wu}$ Y., Xiang X. L., Hu J., Peng Y.Q. Investigation of individual heterozygosity correlated to growth traits in Tongshan Black-boned goat. Molecular Biology Reports. 2013. Vol. 40(11). P. 6075-6079.

16. Iversen M. W., Nordbo O., Gjerlaug-Enger E., Grindflek E., Lopes M. S., Meuwissen T. Effects of heterozygosity on performance of purebred and crossbred pigs. Genetics Selection Evolution. 2019. Vol. 51(1). P. 1-13.

17. Jiang X.P., Liu G. Q., Xiong Y.Z. Investigation of gene and microsatellite heterozygosities correlated to growth rate in the Chinese Meishan pig. Asian-Australasian Journal of Animal Sciences. 2005. Vol. 18(7). P. 927-932.

18. Jiang X. P., Liu G. Q., Wang C., Mao Y. J., Xiong Y.Z. Milk trait heritability and correlation with heterozygosity in yak. Journal of Applied Genetics. 2004. Vol. 45(2). P. 215-224.

19. Kashtanov S. N., Lazebny O. E., Gracheva S. V. Fitness characteristics and allozyme heterozygosity in an artificial population of the sable Martes zibellina L. Russian Journal of Genetics. 2003. Vol. 39(12). P. 1438-1441. 
20. Lieutenant-Gosselin M., Bernatchez L. Local heterozygosity-fitness correlations with global positive effects on fitness in threespine stickleback. Evolution. 2006. Vol. 60(8). P. 1658-1668.

21. Liu G. Q., Jiang X. P., Wang J. Y., Wang Z. Y. Correlations between heterozygosity at microsatellite loci, mean $d^{2}$ and body weight in a Chinese native chicken. Asian-Australasian Journal of Animal Sciences. 2006. Vol. 19(12). P. 1671-1677.

22. Liu G. Q., Jiang X. P., Xiong Y., Deng C., Qu Y. Effects of individual gene heterozygosity on meat quality traits in swine. Journal of Nanjing Agricultural University. 2003. Vol. 26(1). P. 56-60 (in Chinese).

23. Lugovoy S. I., Kharzinova V. R., Kramarenko S. S., Lykhach A. V., Kramarenko A. S., Lykhach V. Y. Genetic polymorphism of microsatellite loci and their association with reproductive traits in Ukrainian meat breed pigs. Cytology and Genetics. 2018. Vol. 52(5). P. 360-367.

24. Luikart G., Pilgrim K., Visty J., Ezenwa V. O., Schwartz M. K. Candidate gene microsatellite variation is associated with parasitism in wild bighorn sheep. Biology Letters. 2008. Vol. 4(2). P. 228-231.

25. Luís C., Cothran E. G., Oom M. D. M. Inbreeding and genetic structure in the endangered Sorraia horse breed: implications for its conservation and management. Journal of Heredity. 2007. Vol. 98(3). P. 232-237.

26. Marshall T.C., Spalton J.A. Simultaneous inbreeding and outbreeding depression in reintroduced Arabian oryx. Animal Conservation. 2000. Vol. 3(3). P. 241-248.

27. Monceau K., Wattier R., Dechaume-Moncharmont F. X., Dubreuil C., Cézilly F. Heterozygosity-fitness correlations in adult and juvenile Zenaida dove, Zenaida aurita. Journal of Heredity. 2013. Vol. 104(1). P. 47-56.

28. Neff B. D. Stabilizing selection on genomic divergence in a wild fish population. Proceedings of the National Academy of Sciences. 2004. Vol. 101(8). P. 2381-2385.

29. Olano-Marin J., Mueller J. C., Kempenaers B. Correlations between heterozygosity and reproductive success in the blue tit (Cyanistes caeruleus): an analysis of inbreeding and single locus effects. Evolution. 2011a. Vol. 65(11). P. 3175-3194.

30. Olano-Marin J., Mueller J. C., Kempenaers B. Heterozygosity and survival in blue tits (Cyanistes caeruleus): contrasting effects of presumably functional and neutral loci. Molecular Ecology. 2011b. Vol. 20(19). P. 4028-4041. 
31. Richardson D. S., Komdeur J., Burke T. Inbreeding in the Seychelles warbler: environment-dependent maternal effects. Evolution. 2004. Vol. 58(9). P. 2037-2048.

32. Saura M., Fernández A., Varona L., Fernández A. I., de Cara M. Á. R., Barragán C., Villanueva B. Detecting inbreeding depression for reproductive traits in Iberian pigs using genome-wide data. Genetics Selection Evolution. 2015. Vol. 47(1). P. 1-9.

33. Singh S. M., Zouros E. Genetic variation associated with growth rate in the American oyster (Crassostrea virginica). Evolution. 1978. Vol. 32(2). P. 342-353.

34. Smith E. M., Hoffman J. I., Green L. E., Amos W. Preliminary association of microsatellite heterozygosity with footrot in domestic sheep. Livestock Science. 2012. Vol. 143(2-3). P. 293-299.

35. Soulsbury C. D., Lebigre C. Viability selection creates negative heterozygosity-fitness correlations in female Black Grouse Lyrurus tetrix. Journal of Ornithology. 2018. Vol. 159(1). P. 93-101.

36. Valilou R. H., Sarskanroud M. R., Rafat S. A., Ebrahimi M., Firouzamandi, M., Mohammadi S. A. Association between footrot resistance and microsatellite polymorphisms of ovar-DRB1 and BMC5221 loci in Iranian Ghezel sheep. Revue de Medecine Veterinaire. 2016. Vol. 167(11-12). P. 316-322.

37. von Hardenberg A., Bassano B., Festa-Bianchet M., Luikart G., Lanfranchi P., Coltman D. Age-dependent genetic effects on a secondary sexual trait in male Alpine ibex, Capra ibex. Molecular Ecology. 2007. Vol. 16(9). P. 1969-1980.

38. Wu X. L., Li X., Merete F. Association of microsatellite genomic heterozygosity with inbred pig performance under successive inbreeding. Acta Genetica Sinica. 2001. Vol. 28(1). P. 20-28 (in Chinese).

39. Zhang J.H., Xiong Y.Z., Deng C.Y. Correlations of genic heterozygosity and variances with heterosis in a pig population revealed by microsatellite DNA marker. Asian-Australasian Journal of Animal Sciences. 2005. Vol. 18(5). P. 620-625.

40. Zouros E. Associative overdominance: evaluating the effects of inbreeding and linkage disequilibrium. Genetica. 1993. Vol.89(1). P. 35-46. 